\title{
Isolation of anaerobes from bubo associated with chancroid
}

\author{
Bhushan Kumar, Vinod K Sharma, Vijay Bakaya, Archana Ayyagiri
}

\begin{abstract}
Ten men with bubo associated with chancroid were studied for bacterial flora especially anaerobes. Anaerobes were isolated from all 10 buboes and eight out of 10 ulcers of chancroid. Anaerobic cocci, $B$ melaninogenicus and $B$ fragilis were the most common isolates. Anaerobes probably play a role in the pathogenesis of bubo in chancroid.
\end{abstract}

\section{Introduction}

Chancroid or ulcus molle, caused by Haemophilus ducreyi, is characterised by multiple sharply circumscribed ulcers with necrotic centre, undermined shaggy erythematous margins and a tender nonindurated base. It results in the development of inflammatory inguinal bubo in approximately half the patients; it may be bilateral in one third of them. ${ }^{1}$ The bubo once developed progresses despite the administration of otherwise effective antimicrobial agents. $^{2}$ The pathogenesis of bubo is unclear; however, $H$ ducreyi has been isolated with lower frequency from bubo compared with ulcers of chancroid. ${ }^{3}$ It is possible that other bacteria play a role in development of the bubo. We studied the microbial flora of inguinal bubo and ulcers in 10 patients with chancroid.

\section{Material and methods}

Ten male patients with clinical diagnosis of chancroid associated with bubo (made by two independent observers) on the basis of clinical features and a negative (repeated thrice) dark field examination, Tzanck and tissue smear, were studied for microbial flora especially anaerobes.

Patients who had received antimicrobials during

The Department of Dermatology

Bhushan Kumar, Vinod K Sharma, Vijay Bakaya

The Department of Medical Microbiology, Postgraduate Institute of Medical Education and Research, Chandigarh, India

Archana Ayyagiri last 5 days were excluded. Blood samples were collected for detection of the HIV antibodies and syphilis serology. Sterile cotton swabs from the edge of the ulcer were immediately transferred into Cary Blair medium and Robertson's cooked meat broth. Each specimen was inoculated on two blood agar (BA) plates and MacConkey's medium. One blood agar plate was incubated aerobically at $37^{\circ} \mathrm{C}$ for 24 hours, the other blood agar plate with haemin and manadione was incubated anaerobically at $37^{\circ} \mathrm{C}$ for 48 hours. After initial culture additional cultures were made on selective media such as Nagler's medium for Clostridia species and Rogosas' medium for lactobacilli if necessary. Various aerobic and anaerobic bacteria were identified by conventional bacteriological techniques. ${ }^{45}$

The bubo aspirate was collected under aseptic conditions using 18 gauge needle and processed in the same manner as the swabs from the genital ulcer. Culture for Haemophilus ducreyi was carried out on both the ulcer swab and on the bubo aspirate.

\section{Results}

All patients were negative for HIV antibodies by ELISA test and VDRL was non-reactive. All were men and their age ranged between 21 to 40 years (mean 25.4). They had 2 to 7 ulcers (mean 4.3) and mean duration of ulceration was $15 \cdot 2$ days. All had penile ulceration associated with fluctuant unruptured bubo, bilateral in 5 patients. $H$ ducreyi was isolated only from ulcer swabs in three of the 10 subjects. The microbial flora of genital ulcers and buboes is depicted in the table. Aerobes like Staphylococcus aureus and $S$ epidermidis were isolated in 7 and 2 genital ulcers. Aerobes, however, were not isolated from bubo aspirate of the same patients. Anaerobes were found in eight out of 10 ulcers and in all buboes. Anaerobic cocci were most common followed by $B$ melaninogenicus and $B$ fragilis. Fusobacteria were isolated in one patient from both genital ulcer and bubo. In all the patients the organisms isolated from the buboes were the same as those from the ulcers.

\section{Discussion}

The diagnosis of chancroid was based on clinical 
Table Microbial isolates from bubo and genital ulcers of chancroid

\begin{tabular}{|c|c|c|c|c|c|}
\hline \multirow{3}{*}{$\begin{array}{l}\text { Case } \\
\text { No }\end{array}$} & \multirow{3}{*}{$\begin{array}{l}\text { Clinical } \\
\text { diagnosis }\end{array}$} & \multicolumn{4}{|l|}{ Microbial isolates from } \\
\hline & & \multicolumn{2}{|l|}{ Bubo } & \multicolumn{2}{|l|}{ Genital ulcer } \\
\hline & & Anaerobes & Aerobes & Anaerobes & Aerobes \\
\hline 1 & Classical chancroid & An cocci, B melaninogenicus & - & - & Staph epidermidis \\
\hline 2 & Classical chancroid & An cocci, B melaninogenicus & - & - & - \\
\hline 3 & Giant chancroid & An cocci, B fragilis & - & An cocci, B fragilis & Staph aureas \\
\hline 4 & Classical chancroid & An cocci, B melaninogenicus & - & An cocci, B melaninogenicus & Staph epidermidis \\
\hline 5 & Classical chancroid & An cocci, Fusobacteria & - & An cocci, Fusobacteria & Staph aureus \\
\hline 6 & Classical chancroid & $\begin{array}{l}\text { An cocci, B melaninogenicus } \\
\text { B fragilis }\end{array}$ & - & $\begin{array}{l}\text { An cocci, B melaninogenicus, } \\
\text { B fragilis }\end{array}$ & Staph aureus \\
\hline 7 & Phagedenic chancroid & An cocci, B melaninogenicus & - & An cocci, B melaninogenicus & Staph aureus \\
\hline 8 & Classical chancroid & $\begin{array}{l}\text { An cocci, B fragilis, } \\
\text { B melaninogenicus }\end{array}$ & - & An cocci, B melaninogenicus & Staph aureus \\
\hline 9 & Classical chancroid & An cocci, $B$ fragilis & - & An cocci, B fragilis & Staph aureus \\
\hline 10 & Classical chancroid & $\begin{array}{l}\text { An cocci, B melaninogenicus, } \\
\text { B fragilis }\end{array}$ & - & $\begin{array}{l}\text { An cocci, B melaninogenicus, } \\
\text { B fragilis }\end{array}$ & Staph aureus \\
\hline
\end{tabular}

grounds. Lymphogranuloma venereum could be easily excluded clinically.

Anaerobes have been implicated in the causation of balanoposthitis, non-specific urethritis and pathogenesis of genital ulcers. ${ }^{367}$ Masfari and coworkers ${ }^{3}$ reported isolation of anaerobes in $77 \%$ of genital ulcers caused by candida and herpes virus. Anaerobes were isolated from $80 \%$ of genital ulcers with chancroid in the present study. Their isolation in all 10 patients with fluctuant unruptured bubo suggests that they may be playing a role in the pathogenesis of bubo. No similar data is available for comparison. Only rarely has tender lymphadenopathy been described with anaerobic balanoposthitis associated with fusospirochaetal infection. ${ }^{8}$ Fusospirochaetes were, however, isolated in only one patient from both bubo and ulcer. Therefore, it is likely that anaerobic cocci, $B$ melaninogenicus and $B$ fragilis play a major role. $B$ ureolyticus and $B$ assachrolyticus implicated in genital ulcers by Masfari and coworkers ${ }^{3}$ were not isolated in our patients. There is a need for further studies on the role of anaerobes in the pathogenesis of bubo in sexually transmitted diseases like chancroid and lymphogranuloma venereum (LGV).

Address for correspondence: Dr Bhushan Kumar, Additional Professor, Department of Dermatology, Postgraduate Institute of Medical Education and Research, Chandigarh-160 012, India.

1 King A, Nicol C, Rodon P. Venereal Diseases. 4th ed. London: English Language Book Society, 1986:251-7.

2 Schmid GP. The treatment of chancroid. JAMA 1986; 255:1757-62.

3 Masfari AN, Kinghorn GR, Hafiz S, Barton IG, Duerden BI. Anaerobic bacteria and herpes simplex virus in genital ulceration. Genitourin Med 1985;61:109-13.

4 Cowan ST. Cowan and Steel's Manual for Identification of Medical Bacteria. 2nd ed. Cambridge: Cambridge University Press, 1974.

5 Holdman LV, Moore WEC. Anaerobic Laboratory Manual. 2nd ed. Virginia: Virginia Polytechnic Institute, 1973.

6 Masfari AN, Kinghorn GR, Duerden BI. Anaerobes in genitourinary infection in men. Br J Venereal Dis 1983;59:255-9.

7 Moss S. Isolation and identification of anaerobic organisms from male and female urogenital tracts. $\mathrm{Br} J$ Venereal Dis 1983;59:182-5.

8 Cree G, Willis AT, Phillips KD. Anaerobic balanoposthitis. $\mathrm{Br}$ Med J 1982;284:859-60. 